\title{
Influence of pruning intensity on light penetration and leaf physiology in high-density orchards of mango trees
}

\author{
Ram Roshan SHARMA ${ }^{a *}$, Room SINGH ${ }^{b}$, Desh Beer SINGH ${ }^{a}$
}

\author{
a Central Institute of Post \\ Harvest Engineering and \\ Technology, Abohar-152-116, \\ India \\ rrs_fht@rediffmail.com \\ $\mathrm{b}$ Division of Fruits and \\ Horticultural Technology, \\ Indian Agricultural Research \\ Institute, New Delhi-110 012, \\ India
}

\section{* Correspondence and reprints}

Received 7 January 2005 Accepted 28 September 2005

Fruits, 2006, vol. 61, p. 117-123 (c) 2006 Cirad/EDP Sciences All rights reserved DOI: 10.1051/fruits:2006010 www.edpsciences.org

RESUMEN ESPAÑOL, p. 123
Influence of pruning intensity on light penetration and leaf physiology in high-density orchards of mango trees.

Abstract - Introduction. High-density orchards of 'Amrapali' mango trees become overcrowded and show progressive decline in yield after 14-15 years of planting; hence, trees require pruning for sustainable production. Reduction in yield in such orchards is due to poor light interception and a low photosynthetic rate, which influence vegetative growth, flower initiation, fruit set and, thereby, the fruit yield. Hence, to help design a tree canopy for optimum plant growth and yield, we studied the effect of pruning on light interception and on different leaf physiological parameters of 'Amrapali' mango trees under high density. Materials and methods. Sixteen-year-old trees of an 'Amrapali' mango high-density orchard were subjected to tipping and light, moderate and heavy pruning; un-pruned trees were used as control. The available photosynthetic photon flux (PPF) and leaf physiological parameters such as rate of photosynthesis, specific leaf weight (SLW) and leaf chlorophyll (Chl) content were measured in pruned and un-pruned tree canopies, following standard procedures. Results and discussion. The percent available PPF was greater in all pruned tree canopies than in un-pruned tree canopies; this could be due to tree openness caused by pruning. The light interception was lower at the lowest height of the tree canopy, probably because the center of the tree canopy was partially blocked by new growth or criss-cross branches. The rate of photosynthesis was greater in leaves that developed in pruned tree canopies than in those developed in un-pruned tree canopies, although there was no difference in SLW; this could be due to better light interception in pruned trees. In contrast, total leaf chlorophyll content was the highest in leaves that developed in un-pruned and tipped tree canopies; this may be due to increased shade owing to overlapping or crowding of tree canopies in these trees, indicating that mango leaves that developed in shade appeared to be more physiologically efficient at synthesizing chlorophyll than leaves that grew in the sun or on the sunny side. Conclusions. The studies indicated that pruning 'Amrapali' mango trees by removing about $10-15 \mathrm{~cm}$ of the top from old branches improves light penetration, which influences the leaf physiology considerably. Hence, it would be useful for designing high-density 'Amrapali' mango orchards to maximize productivity, although it requires additional studies to recommend a particular pruning intensity.

India / Mangifera indica / pruning / planting density / light / leaves / plant physiology / chlorophylls

Influence de l'intensité de la taille sur la pénétration de la lumière et sur la physiologie des feuilles dans un verger de manguiers planté à forte densité.

Résumé - Introduction. Les vergers de manguiers 'Amrapali' plantés à forte densité deviennent surchargés en feuilles et leur rendement baisse progressivement après 14-15 ans de plantation; les arbres doivent donc être taillés pour assurer une production durable. La réduction du rendement dans de tels vergers est due à une faible interception de la lumière dans l'arbre et à un faible taux de photosynthèse qui influence la croissance végétative, l'initiation florale, la nouaison et, de ce fait, le rendement en fruits. Afin de déterminer quelle est la frondaison optimale pour la croissance des plantes et leur production, nous avons étudié l'effet de la taille sur l'interception de la lumière et sur différents paramètres physiologiques de feuilles de manguiers Amrapal plantés à forte densité. Matériel et méthodes. Des manguiers Amrapali âgés de 16 ans, plantés en verger à haute densité, ont été soumis à différents types de taille : pincements des rameaux apicaux ou taille légère, modérée ou lourde des arbres; des manguiers non taillés ont été utilisés comme témoins. Le flux de photons photosynthétiques (FPP) disponibles et les paramètres physiologiques de la feuille comme le taux de photosynthèse, le poids spécifique de feuille (PSF) et la teneur en chlorophylle de la feuille (Chl) ont été mesurés selon des procédures standards dans les frondaisons de manguiers taillés et non taillés. Résultats et discussion. Le taux de PPF disponible a été supérieur dans toutes les frondaisons des arbres taillés, par rapport à celles des arbres non taillés ; cela pourrait être dû à l'éclaircissement de la frondaison provoquée par la taille des arbres. L'interception de la lumière a été plus faible dans les parties inférieures des arbres parce que le centre des frondaisons a été partiellement protégé par la croissance des nouveaux rameaux ou par l'entrecroisement des branches. Le taux de photosynthèse a été plus grand dans les feuilles des arbres taillés que dans celles développées dans les frondaisons d'arbres non taillés, bien qu'il n'y ait eu aucune différence dans PSF ; cela pourrait être dû à une meilleure interception de la lumière dans les arbres taillés. En revanche, Chl a été la plus importante dans les feuilles qui se sont développées dans les frondaisons non taillées et dans celles ayant subi un simple pincement des rameaux ; cela pourrait être dû à un ombrage accru résultant du recouvrement ou de l'encombrement des frondaisons de ces arbres, indiquant que les feuilles de manguiers développées à l'ombre seraient physiologiquement plus efficaces pour synthétiser de la chlorophylle que les feuilles développées au soleil ou dans des zones ensoleillées. Conclusions. Les études ont indiqué que la taille des manguiers Amrapali par suppression d'environ de $(10$ à 15$) \mathrm{cm}$ de vieilles branches améliorait la pénétration de la lumière qui influence considérablement la physiologie de la feuille. Cette taille serait donc utile pour maximiser la productivité de vergers de manguiers Amrapali en forte densité, bien qu'il soit nécessaire d'effectuer des études complémentaires avant de recommander une intensité de taille particulière.

Inde / Mangifera indica / taille / densité de plantation / lumière / feuille / physiologie végétale / chlorophylle 


\section{Introduction}

In India, mango is considered as the "King of fruits". Most of the commercial varieties are vigorous and are therefore grown at a planting distance of 10-12 m, accommodating only $80-100$ trees $h^{-1}$. This results in under-utilization of all the resources, such as irrigation water, manures and fertilizers, etc. Hence, breeding work was re-orientated towards developing precocious, regular and dwarf hybrids at different research stations. The concerted efforts of the mango breeders at the Indian Agricultural Research Institute, New Delhi, India, have resulted in the development of 'Amrapali' (Dashehari $\times$ Neelum), the first popular mango hybrid in the world [1]. Being distinctly dwarf and precocious in bearing, 'Amrapali' was found to be highly suitable for growing at a planting distance of $(2.5 \times 2.5) \mathrm{m}$ in a triangular method, thereby accommodating 1600 trees $^{-1} \mathrm{ha}^{-1}$ [1]. However, later it was observed that high-density orchards of 'Amrapali' mango became overcrowded and showed progressive decline in yield after 14-15 years of planting, and thus required pruning for sustainable production $[2,3]$. Overcrowding of branches results in poor light interception and a low photosynthetic rate. The percentage of light penetration may influence vegetative growth, flower initiation, fruit set and fruit yield invariably [4].

Mango, being an evergreen fruit tree, is rarely selectively pruned. However, previous studies indicate that it responds well to pruning [4-9]. Although some work on the effect of pruning intensity in mango has been conducted in some cultivars by some investigators under conventional plantings, the information on pruning intensity under high-density orchards is lacking. Hence, a systematic and comprehensive study was undertaken to observe the effects of different pruning intensities on light penetration and leaf physiological parameters of 'Amrapali' mango trees under high-density planting, which would be helpful for designing a tree canopy for optimum tree growth, flowering, fruit set and yield of good-quality fruits.

\section{Materials and methods}

Our studies were conducted at the research farm of the Division of Fruits and Horticultural
Technology, Indian Agricultural Research Institute, New Delhi, India, during 2002-2003, on a high-density orchard, consisting of 16-year-old trees of 'Amrapali' mango. The selected trees were of uniform canopy height $(\approx 3.6 \mathrm{~m})$ and spread $(\approx 3.2 \mathrm{~m})$, which were spaced at $(2.5 \times 2.5) \mathrm{m}$ and had never been pruned. Similarly, the selected trees were maintained at uniform cultural practices during the entire period of experimentation and were subjected to different pruning treatments immediately after fruit harvesting in July, 2002, with un-pruned trees as control.

Pruning treatment consisted of tipping (nipping of new growth); removal of a 4 -inch shoot apex from the top (light pruning), 8-inch shoot apex from the top (moderate pruning), and 12-inch shoot apex from the top (heavy pruning). Each treatment consisted of four single trees replicated three times in a factorial randomized block design [10].

The string lines were placed in the NWSE and NE-SW directions through the canopy of each tree at $0.5-\mathrm{m}$ and $1-\mathrm{m}$ heights above the crotch so that measurements of photosynthetic photon flux and leaf physiological parameters could be made at the same place/height [9].

\subsection{Diffuse light availability}

The diffuse light availability was measured as photosynthetic photon flux (PPF) between $10.00 \mathrm{~m}$ and $12.00 \mathrm{~h}$ noon during November and March on five overcast days outside the canopy and between the marks on each line with a Lamda LI-1905 quantum sensor and a Lamda LI-185A light meter, and it was expressed as percent available diffuse PPF, which ranged from $400-600 \mu \mathrm{E} \cdot \mathrm{m}^{-2} \mathrm{~s}^{-1}$ [9].

\subsection{Rate of photosynthesis}

The rate of photosynthesis of the leaves was measured by a portable Infra-Red Gas Analyzer (IRGA) (Hitachi Model) and represented as $\mu \mathrm{mol} \mathrm{CO} 2 \cdot \mathrm{m}^{-2} \cdot \mathrm{s}^{-1}$.

\subsection{Specific leaf weight and leaf chlorophyll content}

The specific leaf weight (SLW) and leaf chlorophyll (Chl) contents were determined 
Table I.

Effect of pruning intensity on diffuse light availability (\% of total) in the canopy of 'Amrapali' mango trees (India).

\begin{tabular}{|c|c|c|c|c|c|c|c|c|c|c|c|c|c|}
\hline \multirow[t]{3}{*}{ Pruning intensity } & \multicolumn{3}{|c|}{ North-west } & \multicolumn{3}{|c|}{ South-east } & \multicolumn{3}{|c|}{ North-east } & \multicolumn{3}{|c|}{ South-west } & \multirow{3}{*}{$\begin{array}{c}\text { Overall } \\
\text { mean }\end{array}$} \\
\hline & \multirow[b]{2}{*}{$0-0.5$} & \multirow[b]{2}{*}{$0.5-1.0$} & \multirow[b]{2}{*}{ Mean } & \multicolumn{6}{|c|}{ Height from the crotch $(m)$} & \multirow[b]{2}{*}{$0-0.5$} & \multirow[b]{2}{*}{$0.5-1.0$} & \multirow[b]{2}{*}{ Mean } & \\
\hline & & & & $0-0.5$ & $0.5-1.0$ & Mean & $0-0.5$ & $0.5-1.0$ & Mean & & & & \\
\hline Tipping & 9.3 & 10.6 & 10.0 & 13.2 & 14.6 & 13.9 & 11.0 & 12.6 & 11.8 & 10.5 & 11.2 & 10.9 & 11.6 \\
\hline Light & 17.3 & 29.1 & 23.2 & 30.2 & 38.6 & 34.4 & 22.3 & 32.6 & 27.5 & 20.3 & 30.1 & 25.2 & 27.6 \\
\hline Moderate & 26.2 & 38.9 & 32.6 & 42.5 & 52.1 & 47.3 & 33.6 & 44.5 & 39.1 & 28.6 & 41.3 & 35.0 & 38.5 \\
\hline Severe & 44.2 & 56.3 & 50.3 & 59.2 & 66.7 & 63.0 & 51.3 & 61.2 & 56.3 & 47.3 & 57.2 & 52.3 & 55.4 \\
\hline Un-pruned (control) & 8.9 & 9.2 & 9.1 & 10.2 & 11.2 & 10.7 & 9.8 & 11.2 & 10.5 & 9.2 & 10.2 & 9.7 & 10.0 \\
\hline Mean & 21.2 & 28.8 & 25.0 & 31.1 & 36.6 & 33.9 & 25.6 & 32.4 & 29.0 & 23.2 & 30.0 & 26.6 & - \\
\hline $\begin{array}{l}\text { Critical differences } \\
(0.05)\end{array}$ & \multicolumn{3}{|c|}{$\begin{array}{c}\text { Pruning }=4.3 \\
\text { Height }=1.6 \\
\text { Pruning } \times \text { height }=5.8\end{array}$} & \multicolumn{3}{|c|}{$\begin{array}{c}\text { Pruning }=4.1 \\
\text { Height }=1.3 \\
\text { Pruning } \times \text { height }=4.9\end{array}$} & \multicolumn{3}{|c|}{$\begin{array}{c}\text { Pruning }=5.3 \\
\text { Height }=2.2 \\
\text { Pruning } \times \text { height }=6.6\end{array}$} & \multicolumn{3}{|c|}{$\begin{array}{c}\text { Pruning }=4.5 \\
\text { Height }=1.8 \\
\text { Pruning } \times \text { height }=5.6\end{array}$} & - \\
\hline
\end{tabular}

from uniform sized leaves of the current season's shoots. For determination of chlorophyll content, eight $0.32-\mathrm{cm}$ leaf discs were removed from each leaf. After washing under tap water in a laboratory, these discs were placed in $10 \mathrm{~mL}$ of $80 \%$ methanol and held in darkness at room temperature for $48 \mathrm{~h}$. After this time, the discs appeared yellow. Chlorophyll content was determined from absorption values obtained at $642 \mathrm{~nm}$ and $664 \mathrm{~nm}$ with a Bausch and Lomb spectronic-21 spectrophotometer, as per the method described by Marini and Marini [9] for peach, and represented as $\mu \mathrm{g} \cdot \mathrm{cm}^{-2}$. For SLW determination, four discs $\left(\approx 30.5 \mathrm{~mm}^{2}\right)$ were sampled with a paper punch from five leaves at each position per tree. The discs were dried at $70{ }^{\circ} \mathrm{C}$ and weighed [4].

A new growth was observed in the pruned trees from August to October. Our measurements indicated that percentages of available PPF, photosynthetic rate, SLW and leaf chlorophyll content were slightly higher in March than in November and the trend for all measurements was the same. Hence, the data were averaged, pooled and subjected to adequate analysis [10], and were not presented separately for November and March measurements.

\section{Results}

\subsection{Diffuse light availability}

The diffuse light availability (percent available PPF) was influenced by pruning intensity, being greater for pruned trees than for un-pruned trees, though non-significant between tipped and un-pruned trees, and slightly affected by canopy direction (table I). Among different pruning intensities, the percent PPF was the maximum (55.4\%) in severely pruned and the minimum (11.6\%) in tipped tree canopies. Further, the percent PPF was greatest (33.9\%) in the SE and the least (25.0\%) in the NW side of the tree canopy. Similarly, the available PPF was greater at the higher point above the crotch $(0.5-$ $1.0 \mathrm{~m})$ than for the lower point $(0-0.5 \mathrm{~m})$.

\subsection{Rate of photosynthesis}

The rate of photosynthesis was significantly influenced by pruning intensity, being highest $\left(7.50 \mathrm{mmol} \mathrm{CO} \cdot \mathrm{m}^{-2} \cdot \mathrm{s}^{-1}\right)$ in leaves that developed following moderate pruning and minimum (4.08 $\mathrm{mmol} \quad \mathrm{CO}_{2} \cdot \mathrm{m}^{-2} \cdot \mathrm{s}^{-1}$ ) in leaves that developed in un-pruned trees (table II). Further, the rate of photosynthesis 
Table II.

Effect of pruning intensity on the rate of photosynthesis $\left(\mu \mathrm{mol} \mathrm{CO} \mathrm{CO}_{2} \cdot \mathrm{m}^{-2} \cdot \mathrm{s}^{-1}\right)$ of 'Amrapali' mango tree canopies (India).

\begin{tabular}{|c|c|c|c|c|c|c|c|c|c|c|c|c|c|}
\hline \multirow[t]{3}{*}{ Pruning intensity } & \multicolumn{3}{|c|}{ North-west } & \multicolumn{3}{|c|}{ South-east } & \multicolumn{3}{|c|}{ North-east } & \multicolumn{3}{|c|}{ South-west } & \multirow{3}{*}{$\begin{array}{l}\text { Overall } \\
\text { mean }\end{array}$} \\
\hline & \multirow[b]{2}{*}{$0-0.5$} & & & \multicolumn{6}{|c|}{ Height from the crotch (m) } & \multirow[b]{2}{*}{$0-0.5$} & \multirow[b]{2}{*}{$0.5-1.0$} & \multirow[b]{2}{*}{ Mean } & \\
\hline & & $0.5-1.0$ & Mean & $0-0.5$ & $0.5-1.0$ & Mean & $0-0.5$ & $0.5-1.0$ & Mean & & & & \\
\hline Tipping & 4.10 & 4.29 & 4.19 & 4.76 & 4.93 & 4.84 & 4.32 & 4.56 & 4.44 & 4.25 & 4.46 & 4.34 & 4.45 \\
\hline Light & 6.66 & 7.01 & 6.83 & 7.06 & 7.66 & 7.36 & 6.96 & 7.39 & 7.17 & 6.77 & 7.16 & 6.96 & 7.08 \\
\hline Moderate & 7.15 & 7.30 & 7.22 & 7.62 & 7.92 & 7.77 & 7.48 & 7.76 & 7.62 & 7.31 & 7.52 & 7.41 & 7.50 \\
\hline Severe & 5.72 & 6.09 & 5.90 & 6.31 & 6.66 & 6.48 & 6.11 & 6.46 & 6.28 & 5.98 & 6.32 & 6.15 & 6.20 \\
\hline Un-pruned (control) & 3.90 & 3.99 & 3.94 & 4.16 & 4.25 & 4.20 & 4.11 & 4.18 & 4.14 & 4.00 & 4.09 & 4.04 & 4.08 \\
\hline Mean & 5.50 & 5.73 & 5.61 & 5.98 & 6.28 & 6.13 & 5.79 & 6.07 & 5.93 & 5.66 & 5.91 & 5.78 & - \\
\hline $\begin{array}{l}\text { Critical differences } \\
(0.05)\end{array}$ & \multicolumn{3}{|c|}{$\begin{array}{c}\text { Pruning }=0.18 \\
\text { Height }=0.12 \\
\text { Pruning } \times \text { height }=0.32\end{array}$} & \multicolumn{3}{|c|}{$\begin{array}{c}\text { Pruning }=0.16 \\
\text { Height }=0.15 \\
\text { Pruning } \times \text { height }=0.36\end{array}$} & \multicolumn{3}{|c|}{$\begin{array}{c}\text { Pruning }=0.11 \\
\text { Height }=0.13 \\
\text { Pruning } \times \text { height }=0.36\end{array}$} & \multicolumn{3}{|c|}{$\begin{array}{c}\text { Pruning }=0.20 \\
\text { Height }=0.17 \\
\text { uning } \times \text { height }=0.36\end{array}$} & - \\
\hline
\end{tabular}

was relatively higher $\left(6.13 \mathrm{mmol} \mathrm{CO} \cdot \mathrm{m}^{-2} \cdot \mathrm{s}^{-1}\right)$ in leaves that developed in the SE side of the tree canopy than those developed in other sides. Similarly, the rate of photosynthesis was lower for leaves that developed at the lower height $(0-0.5 \mathrm{~m})$ than for those developed at the higher height above the crotch $(0.5-1.0 \mathrm{~m})$, which was significantly influenced by different pruning intensities.

\subsection{Specific leaf weight}

There was no significant difference in SLW between leaves that developed in pruned or un-pruned trees (data not shown), regardless of canopy direction or height at which the leaves were developed.

\subsection{Total leaf chlorophyll content}

Total leaf chlorophyll contents were significantly influenced by pruning intensity, being higher in un-pruned $\left(52.3 \mu \mathrm{g} \cdot \mathrm{cm}^{-2}\right)$ and tipped tree canopies $\left(50.1 \mu \cdot \mathrm{cm}^{-2}\right)$ than in severely, moderately and lightly pruned tree canopies (table III). Height from the crotch also influenced leaf chlorophyll content, which was higher at the lower height from the crotch $(0-0.5)$ than at the higher height (0.5-1.0m). Likewise, among different canopy sides, leaves that developed in the SE canopy side had lower $\left(42.6 \mu \mathrm{g} \cdot \mathrm{cm}^{-2}\right)$ chlorophyll content than those developed in other canopy sides.

\section{Discussion}

\subsection{Diffuse light availability}

The diffuse light availability (percent available PPF) was greater for pruned trees than for un-pruned trees, though non-significant between tipped and un-pruned trees, and slightly affected by canopy direction or height from the crotch. Reduced light penetration in un-pruned canopies (control) may presumably be due to increased shading by dense canopy or over-crowding of branches. Light penetration in tipped and un-pruned canopies was also non-significant, primarily because of the non-significant difference in the impact of tipping on the removal of a sizable amount of wood from the trees. In our study, the available PPF (\%) was the highest in the SE side of the tree canopy. These observations differ from the findings of Schaffer and Gaye [4], who reported better light penetration in the NW and SW sides of the tree canopy. This difference may primarily be due to different growing conditions of mango where the studies were conducted. The pattern of light 
Table III.

Effect of pruning intensity on total leaf chlorophyll content $\left(\mu \mathrm{g} \cdot \mathrm{cm}^{-2}\right)$ in 'Amrapali' mango trees (India).

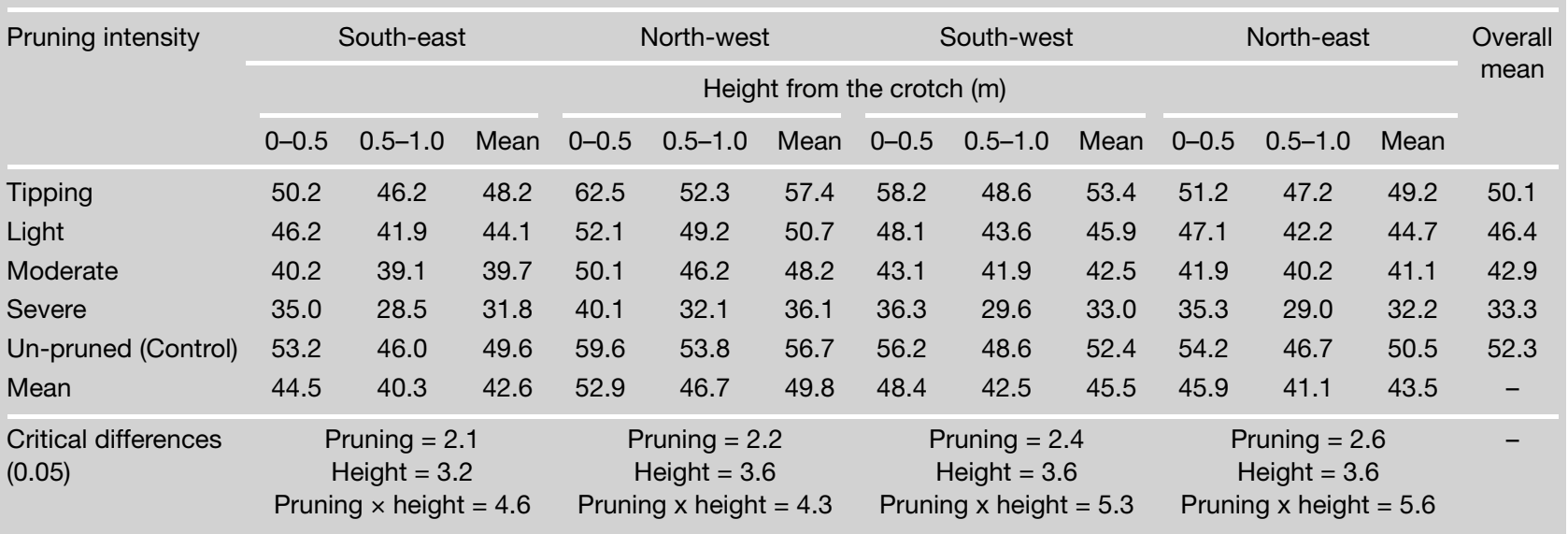

penetration was lower in the center of the tree canopy than at the higher point, probably because the center of the tree was partially blocked by new growth or criss-cross branches [4].

\subsection{Rate of photosynthesis}

The rate of photosynthesis was significantly influenced by pruning intensity, being the highest in leaves that developed after moderate pruning and minimum in leaves that developed in un-pruned trees. It was also relatively higher in leaves that developed in the SE side of the tree canopy and in leaves that developed at the lower height from the crotch. The highest rate of photosynthesis in leaves, which developed in pruned trees or in the SE direction and/or at the highest height from the crotch, may probably be due to better light interception. In contrast, the low rate of photosynthesis in un-pruned tree canopies may be attributed to the long period of shading in un-pruned trees, at tree canopy sides other than SE, and at the low height from the crotch. High interception of light has been reported to favor photosynthesis in many fruits, including mango $[4,9,11]$

\subsection{Specific leaf weight}

No significant difference was observed in specific leaf weight (SLW) of leaves that developed in pruned or un-pruned trees (data not shown), regardless of canopy direction or height at which the leaves were developed. Thus, even better penetration of light in the pruned trees could not influence the SLW of leaves in mango, though Kappel and Flore [12] in peach and Barden [13] in apple had reported greater SLW in leaves with increased light penetration. The reason for this insignificant difference in SLW of leaves in pruned and un-pruned tree canopies is not clear; however, it could be due to the different physiology of mango in comparison to apple and peach.

\subsection{Total leaf chlorophyll content}

Leaf chlorophyll content was significantly influenced by pruning intensity, being higher in un-pruned and tipped tree canopies than in severely, moderately and lightly pruned tree canopies. Higher chlorophyll content in leaves that developed in unpruned and tipped tree canopies than in those developed in heavily, moderately and lightly pruned tree canopies may be due to increased shade owing to overlapping or crowding of tree canopies. Schaffer and Gaye [5] had also reported increased leaf chlorophyll content as percent shade increased in mango. Similar observations have also been made with other fruit species including peach [12] and Citrus [14]. 
Leaf chlorophyll content was higher in leaves that developed at the lower height from the crotch than at the higher height. Similarly, leaves that developed in the SE canopy side had lower chlorophyll content than those developed in other canopy sides. High chlorophyll content in leaves that developed at lower heights from the crotch $(0-0.05 \mathrm{~m})$ and in the NW tree canopy side may also be due to the shade effect of overcrowding branches and canopy [4]. This indicated that mango leaves that developed in shade appeared to be more physiologically efficient at synthesizing chlorophyll than leaves that grew in the sun or on the sunny side.

\section{Conclusions}

Our studies indicated that pruning 'Amrapali' mango trees by removing about 10$15 \mathrm{~cm}$ of the top from old branches improves light penetration, which considerably improves leaf physiology. It would be useful for designing its tree canopy to maximize productivity in high-density orchards. However, additional studies are needed to assess the effect of different pruning intensities on fruit set, yield and quality before recommending a particular pruning intensity for sustainable production.

\section{References}

[1] Majumder P.K., Sharma D.K., Singh R.N., A study on high density orcharding in mango (Mangifera indica L.) var. Amrapali, Punjab Hortic. J. 22 (1982) 123-127.

[2] Majumder P.K., Sharma D.K., A new concept of orcharding in mango, Acta Hortic. 231 (1988) 335-337.

[3] Sharma R.R., Singh C.N., Saxena S.K., Pandey S.N., Chhonkar O.P., Cluster planting favours malformation and influences yield and fruit quality in mango, Ann. Agr. Res. 22 (2001) 48-51.
[4] Schaffer B., Gaye G.O., Effect of pruning on light interception, specific leaf density, leaf chlorophyll content of mango, Scientia Hortic. 41 (1989) 55-61.

[5] Schaffer B., Gaye G.O., Gas exchange, chlorophyll and nitrogen content on mango leaves as influenced by light environment, HortScience 24 (1989) 507-509.

[6] Rao V.N.M., Shanmugavelu K.G., Mango responds to pruning, Indian Hortic. 20 (1975) 5-6.

[7] Oosthuyse S.A., Some principles to mango pruning and the practices adopted for pruning mango trees in South Africa, Acta Hortic. 455 (1997) 413-421.

[8] Lal B., Rajput M.S., Rajan S., Rathore D.S., Effect of pruning on rejuvenation of old mango trees, Indian J. Hortic. 57 (2000) 240242.

[9] Marini R.P., Marini M.C., Seasonal changes in specific leaf weight, net photosynthesis, and chlorophyll content of peach leaves as affected by light penetration and canopy position, J. Am. Soc. Hortic. Sci. 108 (1983) 609-613.

[10] Panse V.G., Sukhatme P.V., Statistical methods for agricultural workers, 4rd ed., Indian Counc. Agric. Res. (ICAR) Publ. New Delhi, India, 1984.

[11] Porpiglia P.J., Barden J.A., Effects of pruning on penetration of photosynthetically active radiation and leaf physiology in apple trees, J. Am. Soc. Hortic. Sci. 106 (1981) 752-754.

[12] Kappel F., Flore J.A., Effect of shade on photosynthesis, specific leaf weight, leaf chlorophyll content, and morphology of young peach trees, J. Am. Soc. Hortic. Sci 108 (1983) 541-544.

[13] Barden J.A., Net photosynthesis, dark respiration, specific leaf weight, and growth of young apple trees as influenced by light regime, J. Am. Soc. Hortic. Sci. 99 (1974) 547-551.

[14] Syvertsen J.P., Light acclimatization in citrus leaves. II. $\mathrm{CO}_{2}$ assimilation and light, water, and nitrogen use efficiency, J. Am. Soc. Hortic. Sci. 109 (1984) 812-817. 
Influencia del tamaño en la intercepción de la luz y en la fisiología de las hojas de mango en vergel plantado bajo densidad alta.

Resumen - Introducción. Los vergeles de mangos "Amrapali" plantados bajo densidad alta se vuelven sobrecargados en relación a sus hojas y su rendimiento baja progresivamente tras 14-15 años de plantación, los árboles deben por lo tanto podarse para garantizar así una producción duradera. La reducción del rendimiento en este tipo de vergeles se debe a una intercepción débil de la luz en el árbol, a un nivel bajo de fotosíntesis que influencia el crecimiento vegetativo, el inicio floral, la fructificación y, correlativamente, el rendimiento de frutos. Con el fin de determinar cuál es el follaje óptimo para el crecimiento de plantas y para su producción respectiva, estudiamos el efecto de la poda en la intercepción de la luz y bajo diferentes parámetros fisiológicos de las hojas de mangos Amrapali plantados bajo alta densidad. Material y métodos. Se sometieron a diferentes tipos de poda sendos mangos Amrapali de 16 años de edad, plantados en vergeles bajo densidad alta: quiebre de las ramas apicales o de tamaño ligero, moderado o pesado de los árboles, mangos sin podar se usaron como testigos. Se midieron de acuerdo con procedimientos estándar en el follaje de mangos podados y no podados: el flujo de fotones fotosintéticos (FPP) disponibles y los parámetros fisiológicos de la hoja como el nivel de fotosíntesis, el peso específico de hoja (PSF) y el contenido de clorofila de la hoja (Chl). Resultados y discusión. El nivel de PPF disponible fue superior en todos los follajes de los árboles podados, en relación con aquellos de los árboles no podados, esto podría deberse al aumento de claridad del follaje provocado por la poda de los árboles. La intercepción de la luz fue más floja en las partes inferiores de los árboles, debido a que el centro de los follajes estuvo particularmente protegido por el crecimiento de nuevas ramas, o por el cruce de las propias ramas. El nivel de fotosíntesis fue mayor en las hojas de los árboles podados que en aquellas que se desarrollaron en el follaje de árboles no podados, bien que no hubo ninguna diferencia en el PSF, esto podría deberse a una intercepción mejor de la luz en los árboles podados. En cambio, Chl fue más importante en las hojas desarrolladas en los follajes no podados y en aquellos en los que hubo un simple quiebre de las ramas; esto podría deberse a una mayor sombra como resultado del grado de cobertura o del amontonamiento de los follajes de estos árboles, indicando que las hojas de mangos desarrollados en la sombra son fisiológicamente más eficientes para sintetizar la clorofila que las hojas desarrolladas al sol o en zonas soleadas. Conclusiones. Los estudios indicaron que la poda de mangos Amrapali con una supresión de alrededor de (10 a 15) cm de las ramas viejas mejora la penetración de la luz que influencia considerablemente la fisiología de la hoja. Esta poda se muestra por lo tanto útil para maximizar la productividad de vergeles de mangos Amrapali de densidad alta, bien que sea necesario efectuar estudios complementarios antes de recomendar una intensidad de la poda particular.

India / Mangifera indica / poda / densidad de plantación / luz / hojas / fisiología vegetal / clorofilas 